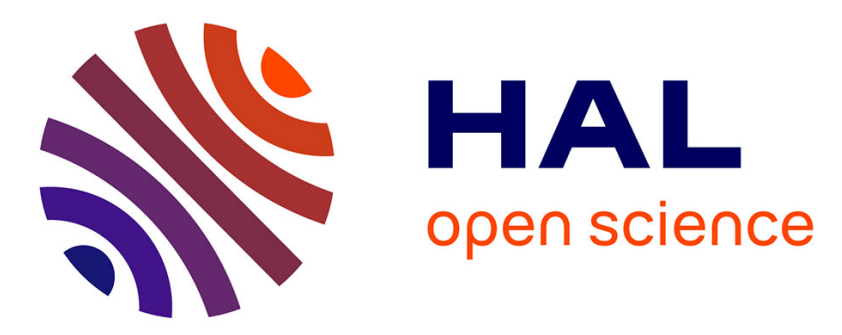

\title{
It takes a quarter of a century to build a dynamic capability: Supplier relations management at Renault (1975-1999)
}

Carole Donada, Gwenaëlle Nogatchewsky, Anne Pezet

\section{- To cite this version:}

Carole Donada, Gwenaëlle Nogatchewsky, Anne Pezet. It takes a quarter of a century to build a dynamic capability: Supplier relations management at Renault (1975-1999). 2014. hal-01070044

\section{HAL Id: hal-01070044 \\ https://essec.hal.science/hal-01070044}

Preprint submitted on 30 Sep 2014

HAL is a multi-disciplinary open access archive for the deposit and dissemination of scientific research documents, whether they are published or not. The documents may come from teaching and research institutions in France or abroad, or from public or private research centers.
L'archive ouverte pluridisciplinaire HAL, est destinée au dépôt et à la diffusion de documents scientifiques de niveau recherche, publiés ou non, émanant des établissements d'enseignement et de recherche français ou étrangers, des laboratoires publics ou privés. 


\section{It Takes a Quarter of a Century to Build a Dynamic Capability}

Research Center

ESSEC Working Paper 1414

2014

Carole Donada

Gwenaëlle Nogatchewsky

Anne Pezet 


\title{
It takes a quarter of a century to build a dynamic capability.
}

Supplier relations management at Renault (1975-1999)

\section{Carole Donada}

\author{
Professor \\ ESSEC Business School \\ Av. Bernard Hirsch \\ 95000 CergyPontoise, France \\ Gwenaëlle Nogatchewsky \\ Maître de conférences \\ DRM-Most (UMR 7088) \\ Université Paris-Dauphine \\ Place du Maréchal de Lattre de Tassigny \\ 75775 Paris Cedex 16, France \\ Anne Pezet \\ Professeur Titulaire \\ HEC Montréal \\ 3000, chemin de la Côte-Sainte-Catherine, \\ Montréal (Québec) H3T 2A7, Canada
}

\begin{abstract}
Summary:
Our analysis explores how a key managerial competence, the supplier relations dynamic capability, was progressively developed and implemented by Renault over a quarter of a century. As our historical approach will demonstrate, this construction process followed three main periods, each of which was characterized by specific external and internal circumstances that constitute turning points and triggers in the organization's transformation decision process. Most importantly, we will argue that this case brings to light that three phases are necessary for the supplier relations dynamic capability to fully develop: hybridization, combination and saturation, which open new perspectives on the construction process of dynamic capabilities in general.
\end{abstract}

\section{INTRODUCTION}


On March 27, 1999, Louis Schweitzer and Carlos Ghosn ${ }^{1}$ announced the creation of the RenaultNissan Alliance, thereby creating the largest industrial and commercial partnership ever signed between a French and a Japanese company. Through this alliance, Nissan agreed to share certain Japanese methods, and more specifically, its quality processes and industrial know-how (lean manufacturing, etc.). Renault brought financial support to the alliance, as well as its supplier management capability, in a context where the latter represents $80 \%$ of the economic added value of a car. A few months later, this alliance gave birth to the Renault Nissan Purchasing Organization, better known under the acronym RNPO. This structure is in charge of purchasing strategies and supplier relations, and was designed to be the cornerstone of the future global and industrial strategy of the two manufacturers. It marked a new beginning for the group, but also came as the culmination of the story of the processes that led towards progressive outsourcing and to the construction of a dynamic capability, namely the supplier relations management dynamic capability.

The goal of this research is therefore to understand how Renault built this dynamic capability. Following in the footsteps of the works begun by Teece (1997), it aims at enriching the corpus of empirical studies dedicated to understanding the mechanisms behind the construction of dynamic capabilities. Our objective is therefore to demonstrate how a strategic dynamic capability is built over time, taking macro-, meso- and micro-economic factors into account, as well as the effect of specific triggers that stimulate these transformations. The triggers help organizations become aware that time for action has come, and it is therefore crucial for companies to be able to identify them. Triggers are elements which, taken individually, could be minor or even insignificant events, but crystallize to make a transformation possible (Hochetand de Jeagere, 2010).

To conduct this research, we have focused on a historical approach to one particular case for a number of reasons. First, a longitudinal study seems particularly relevant to be able to identify the transformation triggers that help build a supplier relations management dynamic capability. On another level, taking into account that dynamic capabilities are idiosyncratic and emerge in a unique fashion in every organization, it seemed essential to us to focus on a case study. We

\footnotetext{
${ }^{1}$ L. Schweitzer was Renault's Chairman and CEO from May 1992 to April 2005, and President of the RenaultNissan Alliance Board from 2001 to 2005. C. Ghosn joined Nissan as its COO in June 1999. He is currently Renault's Chairman and CEO.
} 
therefore studied the Renault case from 1973 to 1999, pursuing the work initiated by Fabre, Nogatchewsky and Pezet, (2010) on the history of the outsourcing policy of this manufacturer. But our use of history is not only a means to integrate the temporal variable in the analysis of a case. It will also enable us to include specific historic considerations in the study of a major organizational phenomenon, such as the diversity and complexity of external and internal influences over a long period of time, the momentum of routines or the role of the company's successive leaders and managers. History also provides us with the opportunity to analyze the construction of a dynamic capability by combining different levels of analysis instead of having to reduce them to one specific level. Finally, the strength of a historical approach lies in the possibility to triangulate multiple sources of data. In our case, those are 1. interviews with those responsible at the time for given choices and actions; 2. Renault's internal records and archives, and its annual reports; 3.external documents from specialized media coverage.

Our analysis will demonstrate that the supplier relations management dynamic capability developed by Renault arose from the evolution of four structural components 1) the company's purchasing strategy, 2) the organizational structure of the purchasing department, 3) individuals and their missions and finally 4) the management tools available. Within these structural elements, we have identified the turning points and triggers in the transformation decision process. The role of the triggers will be underlined in this process so as to reconcile a contingency approach - in which the contingency factors are qualified with precision - and an internal analysis of the organization. Our contribution is therefore theoretical, yet firmly rooted in empirical observations, without which there would be no history.

This article is structured into three main parts. Our first part presents the research design. The second part develops the heart of our research, as it presents a detailed history of the implementation of Renault's outsourcing policy from the three decades of prosperity following WW2 to the creation of the RNPO. Our final section sets out our conclusions. We will discuss the benefits of our historical approach for the analysis of the Renault case, and how it sheds light on the process by which dynamic capabilities are developed and implemented.

\section{RESEARCH DESIGN}

1.1. CONCEPTUAL FRAMEWORK 
For more than 30 years, the resource-base view (RBV) has analyzed strategies based on the creation, development and protection of resources and core competencies within organizations. The relevant authors refer to the thesis of Edith Penrose (1959), who defines organizations as a collection of productive resources, the perpetual combination of which unavoidably leads to their growth. As part of this work, theoreticians were, of course, led to offer their personal definition of productive resources. There are therefore dozens of proposed definitions, but none seem convincing enough to emerge as the leading definition. However, what is accepted by all is that an organization holds tangible and intangible assets, and that these assets are called resources when they are explicitly identified and made available by the organization (Wernerfelt, 1984). The manner in which these resources are deployed depends on the competencies of the organization (Amit and Schoemaker, 1993). From this perspective then, the RBV researchers examined resources and capabilities to identify those that are crucial to build and protect a competitive advantage(Barney, 1991, 1997).

Conducted by Teece [Teece, Pisano, and Shuen (1990a, 1990b, 1997), Teece and Pisano (1994)], an additional theoretical current came to enrich the contributions offered by the RBV that are often deemed too statistical. The main idea they express is that if organizations posses resources and capabilities but do not know how to integrate them, build them and reconfigure them so as to adapt to the evolutions of their environment, they will not be able to sustain supra-competitive returns for the long term except due to chance (Teece, 2007). This idea led to the conceptualization of the theory of dynamic capabilities that, unlike that of the RBV, deals with change. In this conceptual framework, a dynamic capability is the competence to build new competencies (Danneels, 2008). Helfatet al. (2007:4) define it as "the capacity of an organization to purposefully create, extend, or modify its resource base."Helfatet al. identify two types of capabilities: relational capabilities that create, extend, or modify the firm's resource base, to include the resources of its alliance partner; and acquisition-based dynamic capabilities that involve acquiring new resources that are distant from the current knowledge base.

The link between theories of dynamic capabilities on the one hand, and stakeholder theories on the other suggests that we need to take into account the capacity of "individuals and constituencies that contribute either voluntarily or involuntarily to [the firm's] wealth-creating capacity and activities, and who are therefore its potential beneficiaries and/or risk 
bearers"(Post et al., 2002). With the massive development of outsourcing, the strategic management of supplier relationships can therefore become a key capability. The more a company outsources, the more its relational capability becomes key to its performance. Likewise, the more a company outsources, the more it must reinforce its acquisition-based capabilities to better control the suppliers it depends on. In the context of the inter-company exchanges, the relational and acquisition-based capabilities are therefore essential. They are also structurally dynamic, as relationships with suppliers are never stable. They are built depending on market conditions and the resources and capabilities available within an organization.

Understanding the construction of dynamic capability is first and foremost to understand the strategic evolution of the organization which holds it. Numerous authors seek to identify the stages of development of dynamic capabilities. Pablo et al. (2007) describe three phases that consist in managers identifying latent dynamic capabilities, enabling a use of these dynamic capabilities and managing the innovations in accordance with the needs of the organization. Narayanan et al. (2009) identify four phases that are activation (identifying a need for a new capability); articulation (defining the nature of the capability and the implementation principles); mobilization (developing new routines) and implementation (carrying out the projects). Some authors focused on the learning mechanisms. For example, ZolloandWinter (2002) proposed that there are three learning mechanisms that foster the construction of dynamic capabilities: the tacit accumulation of past experience; knowledge articulation and knowledge codification.Others preferred to put forward the role of resources in the construction of dynamic capabilities. For instance, Rothaermeland Hess (2007) studied the effects of the individual level (human capital, notoriety of scientists), the firm level (R\&D), and the network level (alliances with other companies) on the construction of dynamic capabilities. McKelvieandDavidsson (2009) underline the role of tangible resources, such as factories, equipment, computers and machines, and the role of resource flows, i.e. the changes in resources over time as well as the improvement of operational, reputational and technological resources. In parallel, some other authors underline the importance of the role of managers in the development of dynamic capabilities (Teece, 2007; Zahra et al., 2006; AdnerandHelfat, 2003). In this line of thought, AdnerandHelfat (2003) put forward the concept of "dynamic managerial capability", defined as "the capabilities with which managers build, integrate, and reconfigure organizational resources and competences." (p. 1012). The existing literature therefore draws our attention to the interactions between 
managerial human capital, social capital, and cognition. These explanations focus on a number of differential factors.

Despite all these contributions, much remains to be studied to fully understand the complexity of analyzing the construction of a dynamic capability. The benefit of the long historical approach we adopted for this analysis is twofold: on the one hand we will be able to confront these theoretical contributions to the reality of the field; and on the other, we will be able to enrich them by unveiling the complexity of the 25 -year long process of the construction of a dynamic capability.

Three main reasons explain this complexity. First of all, while it is true that the construction of a dynamic capability is the result of strategic choices and appropriate resource allocation depending on the movements of both internal and external environments, it is also the product of unforeseen elements. However, the hypothetical-deductive methodology used in most of the existing literature on this subject does not allow for these elements to be fully apprehended. Secondly, it has been demonstrated that core capabilities are protected by causal ambiguity, making it impossible for observers external to the organization to identify fully, reproduce, or imitate their idiosyncratic characteristics (Lippman and Rumelt, 1982; Reed and De Filippi, 1990). As a result, it is very difficult to understand their construction. Finally, a research project and an organization do not always evolve in compatible timelines. While it might take a company several decades to build dynamic capabilities, a researcher will only have a limited time for his/her analysis. And this precisely underlines the relevance of a historical analysis, based on interviews and archives that can, to a certain extent, help trace the story of a company's development over time.

\subsection{METHODOLOGY}

The use of a historical method in organizational studies requires no further justification thanks to the founding works of Zald $(1993,1996)$. This section will therefore simply expose the relevance of a historical approach to analyze the construction of a dynamic capability. It also aims at demonstrating the strength of our research process, by revealing and commenting the sources used, as well as explaining the chronological divisions that we retained.

The construction of a dynamic capability is, by definition, a phenomenon that is inscribed in time, and therefore can be accounted for through a longitudinal approach. Indeed, longitudinal 
research is an interesting means to understand strategic processes, and a similar approach for the study of dynamic capabilities is therefore particularly fruitful (Helfatet al., 2007). This historicalbased approach is fully inscribed within this methodological perspective, as demonstrates the review of empirical works on dynamic capabilities by Wang and Ahmed (2007).

History is not only a variable. It is also a movement that imposes the depth and complexity of the years through which it travels. This analysis will therefore reveal how Renault progressively built its relational capability with regards to its suppliers.

The sources used for this research ensure the strength of its conclusions. We identified four types of sources (see Annex for details ${ }^{2}$ ):

1) Internal archives from Renault (23 documents): internal memos and correspondences, slides, etc.

2) Semi-structured interviews with those responsible at the time for given choices and actions (17 interviews), mainly with heads of the purchasing, engineering and manufacturing departments. Interviews lasted between 1 to 2.15 hours. Fifteen of them were recorded and integrally transcribed; the remaining two were the object of detailed notes.

3) Documents made public by Renault (48 documents): activity reports, management reports, annual reports, presentedin series.

4) Media coverage from specialized media, archives available on the Renault website and historical studies of Renault.

From these sources, we were able to construct a "story", which we have periodized so as to differentiate the major phases in the construction of the supplier relations management dynamic capability of Renault's purchasing department. Our periodization is based on the major phases of the maturation of the relational dynamic capability that we observed, in particular through the lens of organizational and institutional dimensions.

\section{RENAULT BETWEEN 1975 AND 1999: A HISTORY OF THE CONSTRUCTION OF A CORE COMPETENCE}

\footnotetext{
${ }^{2}$ The Annex that details the sources is not destined to be included in the final version of the article. We have included it here for the reviewers' consideration.
} 
The understanding of events prior to the period analyzed in our research helps us contextualize the decisions made by Renault from 1975 onwards. These events were described in detail by Fabre, NogatchewskyandPezet, (2010). Their research reveals that between 1945 and 1975, Renault justified its choice for a strong vertical integration with rational arguments that are characteristic of periods of shortage and uncertainty "Our Procurement Departmentoften encountered great difficulties in getting the raw materials and accessories that we did not make ourselves from our external suppliers. Much perseverance and unwavering zeal on their part was necessary to ensure that the deliveries we needed were done in due time." (1946 Annual Management Report, p.29). Moreover, the new status of Renault ${ }^{3}$ and the pressures of the Commissariat au Plan(a French institution established in 1946, responsible for defining the economic planning of the country) pushed its CEO Pierre Lefaucheux to declare publicly: "I am [therefore] personally hostile to any reduction of our business activity in favor of any type of company from the private sector " (Annual Management Report 1945, p.13-14).

But the company's model diversification strategy along with the success of the 4CV (a "car for everyone") which was mass produced, shook the foundations of this integrated company. In the 1950s and 1960s, Renault progressively met its internal production capacity limit, forcing it to turn towards offload suppliersto meet the demand. The manufacturer then had to address the need for resources and skills to manage its subcontractors, which were increasing in number every year. In this historical context, it took Renault nearly a quarter of a century to build a strong strategic supplier relationshipmanagement capability. This process, which took place between 1975 and 1999, is marked by three main phases. The first period runs from 1975 to 1984 . During those years, attempts to find the adequate organization were still in their infancy, but the first efforts of instrumentation implemented at the time laid the foundations of the mutation in a context of shortages and crises. The second, from 1985 to 1993, saw the organization of the company's purchasing activities taking shape, and took the critical transition towards evaluation. Finally, from 1994 to 1999, the organization achieved its mutation to become dominant. During this phase, instrumentation structured the exchanges with suppliers to create the relational dynamic capability that Renault brought to Nissan to establish the RNPO. Each period is characterized by

\footnotetext{
${ }^{3}$ The car manufacturer was nationalized by the French government immediately after WW2. Its new name was: The RégieNationale des Usines Renault (RNUR).

${ }^{4}$ Translation is our own.
} 
changes in its strategy, organization, the missions assigned to its staff and the tools used to manage its relations with suppliers.

\subsection{THE DIFFICULT EMERGENCE OF A PURCHASING CAPABILITY IN A PERIOD OF SHORTAGE (1975-1984)}

The second half of the 1970s was marked by a double effect. On the one hand, strong economic growth oriented demand towards cars "for all". As early as 1976, Renault became the first European generalist manufacturer with a market share of about $15 \%$. On the other hand, the high increase in the prices of raw materials created raging inflation. This second state of affairs unbalanced the company's exploitation account as it chose not to reflect the increase in its purchasing prices on its sales price.

However, Renault was looking for new markets and new sources of supply, so Bernard VernierPalliez (CEO from 1975 to 1981) decided to adopt an international focus. In 1978, he signed the company's first major export contracts (Mexico, Portugal and Romania) and launched production operations in lower-cost countries or oil-producing areas (Iran, Colombia, Venezuela and Argentina). For the first time ever, the manufacturer turned to local low-cost suppliers ${ }^{5}$. The same year, Renault also grew closer to the4th largest manufacturer worldwide, American Motors Corporation (AMC) ${ }^{6}$. The merger with Volvo in $1980^{7}$ was a reflection of its international strategy to try and move beyond its difficulties.

In this context then, to face ever-increasing costs and in an attempt to increase its volumes, Renault turned towards a strategy of openness. The economic and commercial results of this policy were not always successful, but it was the opportunity for French engineers and technicians to discover new ways of operating.

\section{An endured procurement strategy rather than a deliberate purchasing strategy.}

\footnotetext{
${ }^{5}$ This strategy did not produce the intended effects, given the political and social instability of these new markets that "proved unreliable and already monopolized by Japanese manufacturers. "Freyssenet (2003).

${ }^{6}$ By progressively increasing its participation in American Motors, by 1979, Renault owned as much as $46 \%$ of its capital.

${ }^{7}$ In 1980, Renault acquired a 15\% stake in Volvo Car Corporation, with an option for an additional 5\%.
} 
No purchasing strategy was explicitly formulated within the company until the 1980s. This lack of strategy was the consequence of Renault's position vis-à-vis raw material and offload suppliers.

On the one hand, the raw-material suppliers were large companies that offered products that were in demand by all industrial companies (for example, Usinor or Sacilor's steel). Therefore, Renault's implicit purchasing strategy was to seduce these powerful parties, even if that meant using unethical practices:

"We were still in the aftermath of an economy of shortages, with a massive demand for raw materials to face our development needs. I have been told that back then, purchasers headed off with $a$ van and bundles of cash and toured the steel retailers to try and get raw materials. It was a real rat race to try and gather tons of steel sheets just to be able to work." [4 Raw Material Purchasing Manager, Purchasing Department].

On the other hand, there was a very large number of offload suppliers, and they were mainly SMEs. Theoretically, this size difference was to Renault's advantage, but its negotiating power was limited because the manufacturer very much depended on these subcontractors to ensure the continuity of the supply for factories in a context of very high demand.

More and more, the company's purchasing practices resembled a makeshift supply chain management, rather than an ambitious and explicit strategy. Aware of the problematic situation, Renault tried to remedy it through a series of actions that were moderate, yet very useful. For example, purchase orders were signed for medium-term periods, never exceeding three months, to ensure relative competitiveness among subcontractors:

"When our purchasers placed orders, they were careful not to give anyone the full workload to make it clear that they were our subcontractors" [2 Industrial Director].

\section{A purchasing organization limited in its responsibilities, competencies and methods}

The purchasing department was directly attached to the General Management, but had only very limited powers. It was a small team, organized by families of products.

"In the 1970s, there were only a few of them. There was a purchasing director (for FRF 8 billion at the end of the 1970s, 11.200 million), under him, there were purchasing managers specialized per families of products (raw materials, electricity, body department, mechanics and capital goods)." [3 Engineer, Technical Department]. 
Purchasers were "guys who stood out", former factory employees, and except for a limited few, with hardly any specific qualifications for this profession ${ }^{8}$.

"Purchasers had little or no formal education, they were kind of crooks, and were not very well paid" [3 Engineer, Technical Department].

"The guys from purchasing weren't exactly bright. When I joined the team in 1969, I was the only person with a degree. The others had managed to stand out in one way or another and had worked their way up. There was just wasn't any point really to ask them what might work on the long run" [4 Raw Material Purchasing Manager, Purchasing Department].

The purchasing department did not have any formalized methods. "Make-do" was the standard way of operating, and the department's tasks were merely reduced to administrative duties, not particularly valued by the hierarchy. Each purchaser dealt with a large number of suppliers (several hundred each), with whom they worked over the phone, without going out to meet them in situ. Buyers seldom left the office premises to meet with suppliers, and contact consisted more in sharing a nice meal together after a quick tour of the factory:

"The guys from Purchasing offered to visit the factory and then to go out for lunch. The standard "formula" was: they [the suppliers] receive us, we eat, and then we talk. "[5 Engineer, Technical Department].

However, the department designed and introduced a first structural outline of the purchasing function. Purchasers were set three targets. The first was to find raw materials: since raw-material suppliers faced high demand, Renault purchasers were expected to "sort themselves out" to ensure that production needs were met. A purchaser from the time described the situation as follows:

"People's main concern was to satisfy the production schedule, rather than refine the price negotiation. ”[4 Raw Material Purchasing Manager, Purchasing Department].

"To meet our objectives, there wasn't much we could do other than court the raw-material suppliers. We took them out to the best restaurants. There was a whole period in which gifts were passed on through purchasers. "[2 Industrial Director].

\footnotetext{
${ }^{8}$ During the 1960s, French universities did not offer any type of specialized trainings for purchasing activities.
} 
The second mission was to "do whatever it took" to avoid shortages and facilitate the delivery of components and subcontracted parts. This role was crucial because Renault's factories were operating at full strength.

"The factory in Flins [in the Paris region] produced 6,000 cars a day. Put end to end, that represents $24 \mathrm{~km}$ of cars in one day. If there weren't enough wheel nuts, none of them could leave the factory. The chains were blocked because one single element was missing. "[3 Engineer, Technical Department].

The third official mission was to select suppliers and products but in reality, the technical teams chose everything. Unlike purchasers, technicians were familiar with the technical capabilities of their suppliers and imposed their choices on purchasers who were only involved at the end of the process, on the administrative side of things. Former technicians told us:

"We talked as technicians, as professionals, as experts. We were the ones who said if they [the suppliers] were limited or not. Our opinion was based on purely technical facts. We knew what was and wasn't possible. Other times, when we suggested one supplier over another, purchasers told us: 'Yes but their hourly rates are too expensive.' Our decision was already made. Costcutting was less important to us than knowing that they would get the job done. Then we were the ones who negotiated the changes, always in hours, and we passed it on to the purchasing department. Then they took the necessary administrative measures to pay them. " 5 Engineer, Technical Department].

When purchasers insisted that the hourly rates of the supplier requested by the technicians were really too high, technicians made 'small adjustments' to maintain their choice.

"We [technicians] did the negotiations ourselves and said: 'This is worth $x$ hours, 'Sometimes we said that the hourly rate was too expensive. So the supplier's answer was: 'Yes, but the purchasing department won't pay me my hourly rate.' And they ended up doing a cross multiplication, to get the amount they wanted. We changed the quote with them, and corrected the amount of hours. Other times, we went to see the purchasing teams to tell them that the hourly rate they requested really wasn't possible because the suppliers had just bought new machines. Sometimes small 'arrangements' were made, and since there weren't any technicians in the team...." [5 Engineer, Technical Department].

"Purchasers gave instructions for the administrative side of things, but the main directions were imposed by the Technical Department. We just couldn't have told a technician we were going to take this lathe if they wanted that one. He would have said: 'Well I need that one. It is the most suitable one, and the one that works best. So you are going to buy that one, and nothing else" [6 Machine Tools Purchasing Manager, Purchasing Department]. 
Over that period, the purchasing department was attached to the general management in the general organization chart, but it had no effective power. Its potential for action was doubly limited by the technical teams on one hand,who defined the specs, and the factories on the other, who dictated the rhythm of supply. Despite the good will of a limited number of people in the company, purchasing teams were not recognized as a source of value creation, and purchasers therefore faced difficulties in trying to achieve their three missions. Into the bargain, the small teams in comparison with the large number of suppliers to deal with, the lack of technical knowledge and the lack of methodological resources meant that they dealt with each transaction at a distance, on a case-by-case basis. And most of the time, their decisions were challenged by their colleagues from the Technical Department or even by suppliers themselves. If it is true that there was a certain will to implement a purchasing organization, it was more of an idea than a factual implementation. The management of purchasing activities was "more quantitative than qualitative" $^{9}$, it relied on handicraft techniques to ensure sufficient supplies, rather than on a real methodology at the service of strategy.

"Be they simple or complicated, relations were all about bargaining. There were no audits, we had no methods" [3 Engineer, Technical Department].

However, the first supplier management tools laid the foundations of an actual purchasing capability.

\section{The signs of a mutation}

The evolution of the purchasing activities between 1975 and 1984 was the product of macroeconomic and sectorial contingencies, such as the reduction of inflation in the second half of the period, the reduction of growth rates and Renault's Europeanization (or even internationalization). But most importantly, what created the conditions for the emergence of a new capability in terms of purchasing management was the rise of four new needs: the need to 1) establish cost analysis methods, 2) use IT tools, 3) increase the levels of qualifications of the purchasers and 4) improve quality.

\footnotetext{
${ }^{9}$ Dixit [4 Raw Material Purchasing Manager, Purchasing Department].
} 
1. Need for value analysis. At the beginning of the 1970s, the first theoretical frameworks on the decomposition of costs resonated with some purchasers, who then started considering new behaviors and methods vis-à-vis their suppliers.

"Towards the end of the 1960s and the beginning of the 1970s, we started to see a shift in behavior that went from haggling to analyzing value, in other words, cost breakdown. It was an analysis of the value of the product: identifying how much the materials were worth, and how much the transformation was worth (salaries, time, etc.). It wasn't easy to get them [suppliers] to reveal the detail of their manufacturing process and costs. Quite often, they didn't even know these details themselves. Some major players such as Saint-Gobain or Michelin even refused to breakdown their prices." [3 Engineer, Technical Department].

To continue this approach, Renault partnered with its French competitor, Peugeot, in the Association Peugeot-Renault for a common policy in terms of purchasing.Peugeot was way ahead in terms of purchasing techniques and value analysis with the Sogedac ${ }^{10}$ :

"Sogedac took part in the negotiations with 2 good purchasers (andperhaps one technician). Renaul came with 10 people, and talked about everything but prices" [6 Machine ToolsPurchasing Managers, Purchasing Department].

The purchasers from Sogedac were feared by suppliers because "these guys were ruthless. They were technically savvy and rummaged around. At the beginning, the Renault purchasers watched them, they were discovering it all." [Manufacturing Director for a supplier].

The collaborations between the two manufacturers became a training vector for the Renault purchasing teams. These were triggers for the mutation of its purchasing practices that had to professionalize.

2. The arrival of IT. The arrival of IT brought with it statistical tools that were necessary to analyze suppliers' performance. It was no longer "felt" but evaluated quantitatively. Whereas previously, information was transmitted orally and informally, IT imposed a strict structuring of information:

"At the time, we had an IBM 64K. All of a sudden, the management of the entire company had to go through these computers. I was entrusted huge jobs, such as transferring all our accounting and inventory onto the computers. It was a huge amount of work, because there was no codification. When everything was transmitted orally, people used data that the computer could

${ }^{10}$ At the time, SOGEDAC was the purchasing arm for Peugeot. 
not process. So we had to become more thorough in our processes." [4 Raw Material Purchasing Manager, Purchasing Department].

3. Demanded qualifications. At the beginning of the $1980 \mathrm{~s}$, the average qualification levels of the purchasers were very low: "My father was a horse dealer, so I knew how to bargain and negotiate" ${ }^{11}$. However, these levels increased regularly. The impetus of this change was given by the recruitment of highly qualified new staff members.

"They created a position for me that was called 'Purchasing Methods.' It made everybody laugh, because they wondered why they had recruited a university graduate for a position that didn't really mean anything to them. What my boss expected me to do was to draw up proposals regarding the organization, structure and the implementation of more modern working methods." [4 Raw Material Purchasing Manager, Purchasing Department].

The company's closer ties with American Motors Corporation (AMC) played a determining role in the awareness that there was a need for higher qualifications. This experience was the opportunity for French engineers and purchasers who went to visit the AMC plants to discover business methods that clearly differentiated procurement and purchasing.

"We had the opportunity to discover the large American suppliers of GM andChrysler. It was an eye-opener. Going to the States was a revelation.’'1 Design Office Manager, Technical Department].

"I think the Americans didn't understand why we were taking them over. We were still 'managing over luncheons' when they were talking purchase marketing. "[2 Industrial Director responsible for the AMC takeover].

Unfortunately, despite this awareness, "we didn't pass it on, and this experience didn't immediately help introduce the tools here. It will be necessary to wait several years so that the awareness is transformed into actions."[1 Design Office Manager, Technical Department].

4. Quality need. From the second half of the 1970s, vehicle defects were becoming a real problem, especially compared to competitors, namely Japanese, who seemed more efficient in that aspect. Purchasers were systematically blamed by the factory personnel:

"Quality is a huge problem. There were a number of quality problems. Numerous incidents were detected at the assembly line. People said: 'Purchasers save three cents to buy rubbish.' "' 3 Engineer, Technical Department].

\footnotetext{
${ }^{11}$ Dixit [6 Machine Tools Purchasing Manager, Purchasing Department].
} 
Renault's General Management then decided to send its teams to Japan to see their quality processes. The purchasers and technicians who went on those trips came back both worried and impressed:

"In Japan we discovered factories that were automated and very organized. The processes were written and pinned on the wall, for everybody to see. Quality reports were presented every two hours and in the evening, there were meetings to understand what had happened during the day. When problems had to do with suppliers, they had to be present. Such efficiency was impressive, and at the same time, it scared us. We didn't want to be like them. "[7 Engineer, Technical Department of Renault Automation].

It was not until the1980s that a long-termquality policy was implemented. This policy deeply affected the purchasing department and its relations with suppliers. The scope of the responsibilities of the former increased, and outsourcing was progressively developed.

In other words, between 1975 and 1984 the purchasing policy was still largely dominated by the Manufacturing and Engineering Departmentsthrough short-term operations in a context highly affected by inflation and growth. But under the impulse of four triggers (AMC experiences, trips to Japan, qualified new employees and its collaboration with Peugeot) and the development of IT tools, little by little purchasers moved away from their procurement duties:

"Little by little we were thinking in terms of purchasing rather than procurement. Rather than running after their parts, purchasers were given more time to think of long-term solutions. This led to agreements with trusted suppliers, through discussions, to obtain better prices, scale effectsand ask for a respect of quality" [3 Engineer, Technical Department].

From that moment onwards, a transformation could take place. At the dawn of the 1980s, the CEO, Bernard Vernier-Pailliez, stated that the industry had to"undergo fundamental transformations" [Letter from the CEO, 1980]. His goal was to modernize Renault so as to obtain competitive cost prices with high-quality products. It was paramount that this modernization took place at every stage of the organization, purchasing department included. From then on, purchasers had to visit their suppliers to ensure that technical regulations were respected [Activity report, 1980] and monitor their quality processes. However, the continuous decrease in sales during the first half of the decade left the company no room to maneuver, as it fell deeper into a major financial crisis. Its CEO Bernard Hanon (appointed in1981), was dismissed in 1985 and 
replaced by Georges Besse ${ }^{12}$, whose clearly stated mission was to restore the company's financial health.

\subsection{THE DEVELOPMENT OF A PURCHASING CAPABILITY TO SATISFY OPERATIONAL GOALS (1985-1993)}

In 1985, Renault was in the midst of a major financial crisis. Its balance sheet was burdened by the liabilities of the previous years. It was in this context, difficult yet conducive to change, that Renault initiated a recovery plan. The plan was announced in June 1985, and it was characterized by two emblematic measures. The first was to refocus on the manufacturer's core business in Europe, which led to the divestment of subsidiaries and the development of outsourcing. The second measure was to improve performance. These two measures forced the purchasing organization to evolve as it was now accountable for attaining the newly set productivity goals. It is in this context that the department implemented practical operational measures by widening the scope of the purchaser's missions, consolidating their competencies and by giving them structured tools (the EAQF).

\section{Definition to improve productivity}

In 1985, for the first time, the name of the Renault Purchasing General Manager was on the first page of the company's activity report. This bears testimony to the recognition of the importance of purchasing by the company's general management. It also provides insight into the crucial role that its new director, Michel Collin ${ }^{13}$, was to have.

"With Collin, purchasing became virtually omnipresent. We were central to the whole company. Everything went through us and was attached to us... And Collin was a strong character, he didn't let anything go and he had Lévy's support, so everything came back to us. "[8 Purchaser, Purchasing Department].

Collin wanted to understand the sources of Japanese performance. He drew inspiration from Toyota's Just-in-Time as well as its project management strategies, the keiretsus ${ }^{14}$,and total quality and cost reduction. These new practices, that would later come to be known as the

\footnotetext{
${ }^{12}$ Georges Besse was murdered in 1986 by a terrorist group, and replaced by Raymond Levy. The latter occupied this position until 1992.

${ }^{13}$ Collin was Purchasing Director until 1994.

${ }^{14}$ Vertical keiretsu are industrial groups connecting manufacturers and captive part suppliers.
} 
"Toyotism Model", were detailed in academic publications (Monden, 1993; Ohno, 1988; Shingo, 1985; Womack et al., 1990). They were disseminated through research programs (e.g. International Motor Vehicle Program by MIT in the States, or the Gerpisa in France or Japan) to which Renault contributed by providing empirical data.

Collin also took advantage of the marking experiences from the previous period (Sogedac and American Motors) to initiate the transformation of the purchasing activity and its practices.

He established two main axes. The first was internal, as it dealt with the structure of the purchasing department and the profiles and missions of the purchasers. The second, more external, was oriented towards supplier relations. His goal was to develop closer ties with some suppliers, and to integrate them into earlier phases of the conception of cars, and to build tools to evaluate suppliers on formal and precise criteria.

\section{A broader internal organizational scheme}

Until the mid-1980s the purchasing department was small in comparison with the engineering and production departments, but the foundations of its transformation had been laid. One of the first actions taken was to broaden the scope of the purchasers' responsibilities. They were now expected to contribute to optimize technical solutions for cost cutting and to negotiate directly with suppliers. The status of purchasing analysts evolved. Their duties were no longer limited to picking up drawings at the design office:

"That period was marked by the end of inflation. We were no longer in a system in which purchasers had to fight suppliers and look for savings. "[9 Purchasing General Manager].

In that context, it is quite naturally that the profile of the purchasers evolved also. More and more qualified business school graduates with a prior knowledge of management methods (management control, finance and marketing, sales, negotiating, etc.) were integrated into the new purchasing teams. The department also recruited specialized technicians and engineers, whose role was to ensure better liaison with the production and engineering departments.

"Over time, the purchasing department evolved. They hired people from the same background as mine (technical). They could actually give some feedback on suppliers and say: 'I saw them, they're not bad. You should go and take a look. We can go together if need be', so the contact with purchasing became more technical." [5 Engineer, Technical Department]. 
"New positions were created, like 'Purchasing Agent'. The technical and purchasing roles merged into one. People from the design teams were included in the purchasing teams. "[9 Purchasing General Manager].

The purchasing teams became tripartite with quality analysts, purchasers, and technicians, and were in direct contact with the other departments, with an explicit purpose [Internal memo from the Purchasing Department, June 5, 1989]:

- Product Department for new services;

- Design/EngineeringDepartment to choose suppliers and technical evolutions;

- Financial Department to analyze supplier risk;

- Sales Department for post-sales strategies, feedback and networking;

- Project Department for development;

- Manufacturing Department for vehicle assembly processes, logistics and quality;

- Quality Department to assess suppliers and training;

- Production Techniques Department for the make or buy decisions;

- Research Department for the research plan.

The purchasing teams were therefore presented as the heart of a large network.In practice, these missions were not homogeneously integrated within the company, but would be later on, for the Twingo project ${ }^{15}$. Well described by Midler (1995), the Twingo project demonstrated how an internal entrepreneurship with a "design to cost" methodology could be used to create an efficient organizational context that could drive all stakeholders to the very key problems of a specific project.

"With the Twingo project, for the first time we had the selling price beforehand. We started to build the car knowing we could not go over a certain price. In the past, we added prices on, and defined our margin afterwards, and from there we determined the market price. "[6 Machine Tools Purchasing Manager, Purchasing Department].

"The suppliers who worked on the Twingo project discovered a brand new working method. The guys from purchasing had changed, they had a different approach. We worked as a team with them for the first time, discussing technical elements and price at the same time. "[Technical Director of one of the suppliers involved in the Twingo Project].

\footnotetext{
15 The Twingo is a small entry-level car.
} 
The collaborative work required for the Twingo Project underlined its efficiency in terms of cost reduction. But in Collin's strategy, this scheme had to be taken further withstricter standards with regards to supplier relations.

\section{A partnerial and technical scheme to select and assess suppliers.}

The strategy to refocus on its core business and increase productivity led Renault to outsource increasingly but to work more with suppliers on the upstream phases of projects.

"From 1986 onwards, we thought we would better perform if we worked upstream with our suppliers. The idea was that purchasers and suppliers should be involved in the design of parts. For purchasers, being involved in the design phase would help them understand the issues, and they would therefore be better equipped to negotiate with suppliers for the parts that they bought. "[9 Purchasing General Manager].

Moreover, the cost-cutting strategy also required that they reduce the number of suppliers with whom they worked. Taking inspiration from the privileged relationship between Toyota and its keiretsus, Renault decided to implement a partnerial scheme with a limited number of suppliers.

Partnerships were a new concept for the manufacturer. The first partnership, signed on February 13, 1986, was a binding contractual agreement between Renault and its smelter and mechanical suppliers. A couple of months later, after a report by the French Ministry of Industry (also known as the "DalleReport") which presented the principles of vertical relations in Japan, Renault published a Charter of Supplier Relations. The document began with a definition of "partner", and explained the advantages of the partnership approach and its key success factors. It mentioned that a partner must be a profitable and competitive company, with a multimanufacturingclientele at an international level, capable of mastering a function, with a process of total quality, with the capability to offer a critical assessment of the specs and with a good manpower management (managing teams, social climate, and corporate projects). This first definition became one of the bases of the strategy of the manufacturer until 1999.

Beyond these main principles, these partnerial relationships could not be dissociated from the need for a more instrumented assessment process of its suppliers. Renault decided to work on the certification criteria of its suppliers. The scope of the QCD(Quality, Cost, Delivery) was 
extended from its initial three simple criteria to seven, to include: ability to offer high quality products, financial management, price competitiveness, innovation potential and technical collaboration potential, capability to export, management, and reliable logistics [Activity Report management elements 1986].

But what really structured these partnerial relations with suppliers were the evaluation tools implemented through the EAQF ${ }^{16}$ processes. The EAQF was implemented with the SOGEDAC, and its goals were to assess the suppliers on their ability to supply products and processes which complied with the QCD criteria.

"The first EAQF were based on audits (initially 7 purchasing criteria) and improvement plans. The idea at the time was to say that if suppliers provided good quality, they would also be efficient. The EAQF was therefore designed as a steering tool for quality, but also a lever for industrial and economic performance. In parallel to these quality initiatives, the company also implemented the Just-in-Time, which became another performance lever. "[9 Purchasing General Manager].

With the EAQF, purchasers became the liaison point of the company's relations with its suppliers.

"We (at the engineering department) weren't really allowed to go to the suppliers on our own. With the new organization, we had to inform the purchaser that we wanted to go, and then we would go together. The change didn't come naturally or spontaneously. The EAQF tool federated us, and it was all the easier since purchasers were more familiar with their activity." [1 Design Office Manager, Technical Department].

In 1988, approximately 300 supplier financial analyses were performed. The benefits of the EAQF for Renault became obvious shortly after its launch.

- It was a tool that helped identify priorities:

"The EAQF had the advantage of being very targeted. There were several general sections on the organization of the supplier, even on the service that analyzed costs and of their financial department. Then there were chapters for each type of technology, and chapters on their supply chain management. There were 4 levels of assessment: $A, B, C, D$. For example, $D$ could be for those who weren't the critical size. To be an A, they had to score a grade that was above $90 \%$." [1 Design Office Manager, Technical Department].

- It was designed as a comprehensive tool:

\footnotetext{
${ }^{16}$ Stands for Évaluation Aptitude QualitéFournisseurs: Quality aptitude evaluation of suppliers.
} 
"It took us three full days. And there were about 5 or 6 of us every time. There was always at least one person with sound technical knowledge, one who knew about finance, and another with some basic knowledge of quality. Our suppliers had to open their doors to us for three full days. We welcomed them beforehand and explained what we were going to check. The supplier had to have all the documents ready and prepare a room for us, and then, we went to check if indeed, reality matched the documents. "[6 Machine Tools Purchasing Manager, Purchasing Department].

- This tool was rational, and imposedthoroughness:

"I think that EAQF helped us think and act in more thorough and systematic terms. From the moment a supplier had received the same EAQF grade than another, the technical teams could no longer say that it was not suitable. From the point of view of control, we had noticed that nothing had ever really been in place. There was no control of the measurement tools, no calibration chain, no equipment index. Each worker had his/her own sliding calipers in his/her drawer and they were never calibrated. There was no control. When we started the EAQF, all that changed. There was a list of all the equipment, the control dates, etc. "[6 Machine Tools Purchasing Manager, Purchasing Department].

The assessment grids evolved constantly to integrate more and more criteria, which bears witness to the company's efforts to ensure continuous improvement. In a way then, Renault implemented its continuous improvement management (a type of management developed and in vogue at the time in a large number of organizations) through the EAQF:

"The first steps of the EAQF introduced 'statistical controls of factory processes... the first tools ever implemented in our factories' [13 Re-engineering Manager, Purchasing Department] then, the tools became more sophisticated "there was a first version in 1988-1989 that focused on approximately 100 criteria, then this referential was improved."[6 Machine Tools Purchasing Manager, Purchasing Department].

To summarize Renault's purchasing policy between 1985 and 1993 was dictated by its recovery plan, and the financial difficulties it was experiencing. In that context, there were two important triggers: 1) the refocus on the core business and productivity and 2) the arrival of a new Purchasing General Manager, who imposed his legitimacy (M. Collin) and ensured that the strategy, practices and the organization of the purchasing department were progressively placed at the heart of the company's strategy. In parallel, the experience of the Twingo Project and its Toyotism influences, opened new perspectives to reduce upstream costs and improve the quality of both projects and processes alike. 
By the end of 1987, Renault reported the best results in its history, thanks to a significant improvement of its margins. The partnership strategy with some of its large suppliers was directly linked to this success.

\subsection{THE DEPLOYMENT OF THE SUPPLIER RELATIONS MANAGEMENT DYNAMIC CAPABILITY (1994-1999)}

Louis Schweitzer was named CEO of Renault in 1992. He is the man behind the privatization of the group and its Alliance with the Japanese manufacturer Nissan. In 1994, the French state reduced its holding to $53 \%$, and the remainder was publicly quoted on the French stock market. Renault's privatization became effective on July 15, 1996 ${ }^{17}$. In that context, the financial performance objectives were raised, and the company's general management launched a new cost-reduction plan.

The plan was based on massive outsourcing, the implementation of lean manufacturinginitiated by Toyota, and a project-based organizational structure. The general organization chart became matrix-based, to integrate the design teams within the industrialization teams. This transformation led to the inauguration in 1998 of an unique research center for the company's new products: The Technocentre based in Guyancourt (in the Paris Region) and its Ruche with 12.000 staff members ${ }^{18}$. The site was designed to bring together all the actors involved in the design of a new vehicle.

General Management quantified the goals of this restructuring: reduce the length of the development of new models from 60 to 38 months; save FRF 1.5 billion (€230 million) in development and investment costs for each new vehicle; reduce the vehicle costs by FRF 3000 (€ 457) per car and generalize an assembly time of 15 hours per car. In the strategic projections that were defined for the following 15 years, the car manufacturer was to progressively evolve to the position of automotive integrator.

\footnotetext{
${ }^{17}$ In 1990, Renault had already changed its status to become a Limited company owned by the French State.

${ }^{18}$ At the Technocentre, La Ruche (the hive) is a specific architectural structure designed to facilitate the flow of information: the building is circle-shaped, the open space plans are placed around wells of light. Circular balconies go all around the inside of the hive, and each car project has a designated level. But everyone can see everybody else, and it is easy to get around. This structure therefore facilitated information flows.
} 
These changes and projections led to a re-engineering of the purchasing department that "represented $90 \%$ of the production cost at the time." 19 . This re-engineering focused on the reformalization of the purchasing strategy and a re-structuring of the supplier relations.

\section{The re-engineering of the purchasing department}

To satisfy these general objectives, Jean Baptiste Duzan was named as the new Purchasing

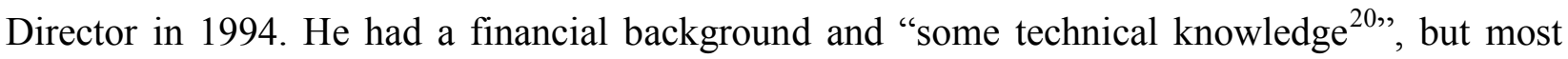
importantly, he knew how to capitalize on his predecessors' efforts to fully restructure his department. The first thing he did was to change its name: the Purchasing Department therefore became the Supplier Relations Department. This change is far from insignificant, and the transformation is much more than merely formal.

"During the re-engineering, they wanted to promote the structural changes. The expression 'Supplier Relations Department' instead of 'Purchasing Department' or 'Supplier Relations Manager' [SRM] instead of 'Purchasing Manager' or 'purchasing officer' was a way of expressing change in core competence, and how the organization was going to change." [13 Reengineering Manager, Purchasing Department].

The fact that they altogether abandoned the word "purchasing" is symbolic of a major strategic shift that required a new managing team, reinforced by the integration of new groups of experts in charge of strategy, management control, human resources, legal affairs, international affairs, quality and supplier development ${ }^{21}$.

The purchasing structure also became matrix-based. Purchasers were no longer organized vertically, in families, but rather in projects. For each project, there was therefore a Purchasing Project Manager, assisted by Purchasing Project Agents (PPA) and Production Commodity Buyers (PCB) for each family.

\footnotetext{
${ }^{19}$ [Internal presentation by the Key Account Manager for Purchasing Strategy, Purchasing Department, 1998].

${ }^{20}$ dixit[1 Design Office Manager, Technical Department].

${ }^{21}$ [Internal note by J.BDuzan, January 13, 1998; Presentation by the Purchasing Department, 1998].
} 
"We shifted from an activity-based organization to a project-based organization... Each project had a dedicated purchasing team that reported to the General Manager. It was well balanced. "[10 Supplier Relations Manager, Purchasing Department].

The person responsible for the transversal coordination of the matrix was the SRM who defined the purchasing strategy for each family of products. With regards to the former function in the vertical structure, the SRM no longer had the hierarchical responsibility of the teams.

"I negotiated the guys' raises and mobility, but in their activities, it was the Purchasing Manager who managed them."'[11 Project Purchasing Director, Purchasing Team].

In this matrix, the managerial primacy fell to the project managers and the strategic primacy to the SRM. The dichotomy Manufacturing-engineering/purchasing from times past had disappeared. Technicians and purchasers were brought together in teams at the Technocentre.

"The 25 project purchasers were grouped by geographical function of the vehicle. They were near the engineering, the design offices. The design of the building was not a coincidence. "[11 Project Purchasing Director, Purchasing Team].

\section{A formalized strategy based on performance through cost-reduction}

The purchasing strategy was officially formalized in 1995 with the creation of the Upstream Function Strategic Group ${ }^{22}$. This group counted both purchasers and technicians. Its role was to track upstream innovations, understand future evolutions of suppliers and to take into account the globalization of exchanges to define country-based strategies. They were expected to define strategic plans on a three-year horizon.

"The strategic committee brought the purchasing, engineering, manufacturing and product development departments together to think of long-term strategies. "[10 Supplier Relations Manager, Purchasing Department].

"The strategies were formalized during a committee meeting that was held every two years with the Purchasing Director along with the Engineering and Manufacturing Directors concerned. "[12 Supplier Relations Manager, Purchasing Department].

\footnotetext{
${ }^{22}$ In French: Groupe Stratégique de Fonction Amont (GSFA)
} 
The Purchasing team's primary strategic goal was to reduce the cost price per car by FRF 3000 (€457) [Annual Report, 1996]. One of the key strengths of the Synergie program launched ${ }^{23}$ between 1995 and 1996 to achieve this goal was that it rebalanced the productivity gains, with an even split between technical gains (50\%) and commercial gains (also 50\%).[9 Purchasing General Manager]. This goal was ambitious because at the beginning of $1995,95 \%$ of the reduction of purchasing costs still came from commercial productivities. From then on, Renault had to ask its suppliers explicitly to take on the major part of the cost reduction, thereby making them become the co-designers of Renault's value creation.

\section{A new relational framework with partners of excellence}

Renault's expectations of its suppliers were clearly expressed by Duzan. They were expected to achieve a $6 \%$ increase in their productivity every year, offer cost-reduction ideas, help the manufacturer benefit from their international implantation, structure their purchasing departments as Renault organizes its own and not hesitate to outsource when necessary ${ }^{24}$.

For the outsourcing of performance to work, it became necessary to further professionalize its supplier assessment scheme, in order to select those who could join the panel of excellence partners.

\section{Evaluation, forever and always}

The EAQF referential implemented during the previous period remained the absolute reference for auditing quality systems. However, the EAQF underwent some changes. Quantitatively, the initial forty criteria at the end of the 1980s were extended to about 140 in 1994. Qualitatively, Renault also started outsourcing said evaluation, by passing on the responsibility of audits directly to the suppliers themselves.

"At the beginning, we performed these evaluations alone. When we changed the EAQF to 140 criteria (named EAQF 9425), we appointed certification companies. Until finally we let the suppliers take on this responsibility and requested to have access to the data. In any case, with

\footnotetext{
${ }^{23}$ Renault took example on the experience of other manufacturers. As early as 1989, Chrysler had launched the SCORE (Supplier Cost Reduction Effort) program. Honda, Ford, Toyota, etc. followedthisexample. 24[Interview with Jean-Baptiste Duzan in La Tribune Desfossés, "Renault : pour le moindre coût, oui à la délocalisation des fournisseurs", Friday October 13, 1995, p. 10].

${ }^{25}$ The EAQF94 was replaced by the ISO certification in the 2000s, but the referential from 1994 already contained the key chapters of the ISO 9001.
} 
this tool, we knew everything there was to know. " [6 Machine Tools Purchasing Manager, Purchasing Department].

The EAQF94 approach was perfectly suited to the organization's re-engineering, because it could help evaluate the alignment between design, processes and products. In this context, the two chapters containing the largest number of criteria were:

- "Design Management: project-based organization, managementof product design, management of design processes" (27 criteria).

- $\quad$ "Process Management: prepare and organize production, ensure quality within production (21 criteria).

The tool was less efficient on some important aspects, for example the feasibility study only included one criterion, or there were only two for predictive reliability. However, Renault added a list of complementary indicators to better assess the suppliers' $R \& D$, management, human Resources and financial management. Finally, and more specifically, the purchase of capital goods was administered by the Production Quality Assurance (PQA) ${ }^{26}$ and the purchase of consumables by the Product and Process Quality Assurance (PPQA) ${ }^{27}$. The monitoring and assessment instruments for suppliers increased in number and complexity, to be able to identify partners of excellence. On a scale from A to D, Renault agreed to work exclusively with A or B suppliers, if they had a well-defined progress plan.

\section{Optima complement to build a panel of partners}

Renault's relational capability was therefore structured around clear goals and formal evaluation tools and programs. From that point of view, the period beginning in 1994 was crucial. Synergie 500 was soon supplemented by the Optima program, which furthered and professionalized the partnership agreements from the previous decade.

"The optima program represented strong relations with suppliers, with long-term commitments as well as cost reduction, lean manufacturing, product optimization... it was implemented in 1995-1997, at the same time as the organizational transformation with the creation of the Supplier Relations Managers. Duzan and I were those who launched and promoted the program."[13 Re-engineering Manager, Purchasing Department].

\footnotetext{
${ }^{26}$ In French: Assurance Qualité Moyens de Production et Constat Qualité Prestation (AQM/CQP) ${ }_{27}$ In French: Assurance QualitéProduit Process (AQPP)
} 
A new Partnership Charter was formulated in 1997. It established the framework of a renewed understanding of these relations, with a win-win spirit, a daily quest for high performance, in a climate of mutual trust, [Partnership Charter, January 1998]. The motto of the era was the winwin partnership. Its general principle was formulated as: "Renault's competitiveness in the market will only be possible thanks to its network of suppliers" to, with them "be the best on the markets in terms of product and service quality, reduce production costs and offer a young, strong and innovative range of products" [Internal document "Partnership Charter"; accompanying slides, November 1997]. Optima was therefore implemented to ensure the best possible Renault/supplier system and the lowest possible Renault/supplier costs.

Its principles were as follows:

- $\quad$ "develop trust, technical and financial transparency, solidarity and complementarities,

- $\quad$ so that each can meet their strategic goals, mainly financial,

- $\quad$ resolve problems thanks to team work,

- $\quad$ and prevent having to systematically rely on competitiveness." 28

The Charter lead to a practical application: a list of selected Optima suppliers (a total of 39 Optima suppliers at the end of 1998$)^{29}$.

\section{The need for a relation management capability}

The Optima partnership wasnon-contractual or only little. It was only a formal foundation, around three core values: trust, transparency and solidarity [Purchasing Department Internal Communication document, January 1999].

In that context, it became essential for Renault to mobilize all its relational resources to ensure that the Optima suppliers effectively committed to offering them their innovations in priority, to respect the goals by joining the programs launched by the manufacturer, to take corrective measures when necessary and to receive Renault's help and expertise ${ }^{30}$. In return, Renault committed to stabilizing the market share of its suppliers, to not pitting them against competitors,

\footnotetext{
28 [Internal Document "Partnership Charter"; accompanying slideshow kit, November 1997]

${ }^{29}$ [Slides presented during the suppliers convention held in December 1999]

${ }^{30}$ [Slide show for a presentation by the Key Account Manager for Purchasing Strategy, Purchasing Department, April 1998]
} 
and even to sharing its strategy with them. These responsibilities fell to the Supplier Relations Managers.

Also, to allow for efficient management of its relations with its partners, the allocation of responsibilities between Renault and the Optima suppliers was formalized. On the one hand, Renault was to ensure that it always maintained its contracting ownership, while taking into account the suppliers' skills and contributions, and on the otherhand, that the latter were responsible for:

- Development, based on the functional specifications: "the supplier acts as an internal engineering department. Renault will not perform systematic controls of the supplier's activities.”

- the integration of the function in the vehicle: "The supplier will second a residing engineer to the work with the project team during critical development phases",

- $\quad$ purchasing, quality and logistics with tier II suppliers,

- $\quad$ optimizingseries products ${ }^{31}$.

At the same time, Renault also launched a reflection on a subsidiary-based management, and not only with Tier I suppliers. This approach would therefore prevent Tier I suppliers from reflecting the cost pressure on Tier II suppliers, which would be prejudicial to Renault [Internal Note by 8 Key Account Manager for Purchasing Strategy, Purchasing Department, July 10, 1995]. Finally, the manufacturer joined the Barcelona Suppliers Collective Agreement that fostered trust, longterm relations andfair play [Summary of the Suppliers Collective Agreement of 1997].

This marked the beginning of a new managerial mode, which was developed thanks to massive outsourcing. From then on, the resources and skills that were mobilized were complementary, to adapt to the supplier relations that had shifted towards a shared understanding of performance. The difference now resided in "the quality and the trust of the relation between the manufacturer as a whole and its panel, and also... on the way in which technology transfers are obtained... Therefore, it is the human and the organizational relations alike that will ensure the performance of the whole."'Internal Memo by 8 the Key Account Manager for Purchasing Strategy, Purchasing Department, July 10, 2985].

\footnotetext{
${ }^{31}$ [Internal document, "Partnership Charter", January 1998]
} 
In summary, the purchasing policy between 1994 and 1999 was established within important contextual and organizational changes. Renault initiated a deep-rooted change regarding its suppliers. If evaluation remained the anchor point of the method, the range of programs that were implemented after 1994, such as Optima and Synergie 500, illustrate the manufacturer's intention to delegate, or outsource, a large part of its performance creation. These programs strongly structured the relations between Renault and its suppliers, and implemented the supplier relations strategic management capability both at Renault and its suppliers. This capability flourished with the establishment of RNPO.

\section{CONTRIBUTION AND CONCLUSION}

A dynamic capability is defined by Helfatet al. as (2007) "the capacity of an organization to purposefully create, extend or modify its resource base." (p. 1). Dynamic capabilities therefore help an organization survive and thrive when faced with change. They take on multiple forms:Helfatet al. (2007) dividedthem into three broad categories - alliances, acquisitions and management. However, not every dynamic capability falls into these three categories. As a consequence, the use of a historical method helps us analyze this subject at hand by combining the various analysis levels, rather than reducing them to one particular level. Our contribution thereby highlights how a dynamic capability was developed over a 25 -year period, on an essentially managerial basis to later evolve into an alliance. Indeed, successive directors progressively transformed what had been the constraints of outsourcing into opportunities. Each of them, with their own particular values and strategies, transformed a resource base (i.e. tangible, intangible and human assets), along with what would become the core dynamic capability of the Renault Nissan Alliance: supplier relations management dynamic capability.

As outlined in section 1.1., the question of building dynamic capabilities has been the object of a wide range of works, in which we find two major approaches. On the one hand, there are the works which focus on the processes and describe the phases of the construction of a capability (Pablo et al., 2007; Narayanan et al., 2009). And on the other, some works identify variables (human, organizational, financial, technological, etc.) that explain the construction of dynamic capabilities (ZolloandWinter, 2002; AdnerandHelfat, 2003; Zahra et al., 2006; Rothaermeland Hess, 2007; Teece, 2007; McKelvieandDavidsson, 2009). These studies by no means cover the 
full extent of the complexity of the matter, and a lot remains to be studied to understand the combination of dimensions at play in the construction of a dynamic capability. The relevance of a historical analysis is to root the concept in the complexity of the real world and its timeline because "dynamic capabilities not only have generic attributes, but also become tailored to the settings in which they function, including different industries, technologies, functional areas, and organizations" (Helfatet al., 2007, p. 7). The identified phases and variables in the works mentioned earlier are relevant, but a historical analysis brings them to life, and enriches them.

\section{$<$ Insert figure 1 here $>$}

The attached diagram helps visualize the dynamism of the process in which time is more than a simple variable. A historical-based approach makes it possible to include in the analysis of a major organizational phenomenon, i.e. building capabilities, characteristics that are specific to the company's history, such as context, the dynamics of its processes over time, the diversity and complexity of possible causes and influences, and the role of leaders and managers. The figurehighlights how the supplier relationship capability was built, in a general and strategic context of a near-exponential increase of its outsourcing, driven by a set of triggers (from the emergence of IT to globalization). The organization then turned towards building a new intangible asset through four lines of action: the place of purchasing in the company, the roles and targets of the people involved, the tools implemented and finally, a new understanding of supplier relationships.

By introducing the concept of trigger, we shed light on one of the motors of the underlying dynamism of capabilities. As Winter (2003) previously demonstrated, what differentiates a capability from a simple matter of problem-solving or a circumstantial adaptation to a given situation, lies in the presence of patterned elements. The concept of trigger, defined by Hochetand de Jaegere (2010), is what reveals this pattern:

"The challenge a manager-transformer is faced with can be summarized in one word: discernment... The effective capability of a company to identify the problems, understand the transformation challenges and integrate the complexity and multiplicity of constraints becomes determining. This ability testifies to the level maturity of the company with regards to transformation. Discernment must therefore begin with an exercise of lucidity regarding:

the assessment of the impact of the mutations as triggers for transformation, 
- $\quad$ the re-evaluation of the reading grids allowing to better apprehend emerging phenomena - $\quad$ the ability to change the rules of the game". ${ }^{32}$

Therefore, the major challenge for monitoring and steering schemes is to anticipate the inflection points, i.e. the moment in which the model stops being valid. But to engage a transformation decision process, a trigger is required". In other words, the heart of the transformation lies in the "conditions for an external or internal circumstance - which if taken alone, can be a minor event which crystallizes and becomes a genuine trigger" (Hochetand de Jaegere, 2010, p. XX).

The inductive approach of history helped us identify these elements, diverse in nature, without prior hierarchy. What is important here is not so much to identify crucial generic factors, as to lay bare the punctual crystallization of elements of the internal and external context of the company in a form that is actionable by managers. The Renault case has therefore made it possible to unveil the fine texture of characteristic patterns of dynamic capabilities through the concept of triggers. They vary in nature, with for example the arrival of a new manager or new qualifications, international experiences, or new management modes (see figure 1). We thereby highlight how the intentionality that characterizes dynamic capabilities, (referred to as "purposefully" in the definition above) takes shape. Our historical analysis helped us identify three types of events that are not dynamic capabilities per se, but that became dynamic capabilities when actors "pulled the trigger", i.e. when they used the internal or external event to transform the resource base of the organization (see figure 2).

$<$ Insert figure 2 here $>$

Moreover, the true stake of the analysis of dynamic capabilities resides less in the 'what' than in the 'how'. Indeed they are not available on the market, but must be developed and deployed. By using a historical timeline, we were able to reveal how this development process was implemented. The Renault case brings to light that three phases are necessary for the supplier relations management dynamic capability to fully develop: hybridization, combination and saturation, that align with the three stages of creation, development and deployment of a dynamic capability(Helfatet al., 2007, p. 30-1). The historical analysis of the Renault case has therefore helped us characterize these phases with precision.

\footnotetext{
${ }^{32}$ Translation is our own.
} 
The first phase, from the mid-1970s to the mid-1980s was characterized by the diversity of external input (Sogedac, American Motors Corporation, Japanese methods and the recruitment of young Business School graduates) and most importantly by the cross-fertilization that resulted from it. The different factors present in the environment and that were known by Renault were not enough however to create this dynamic capability: Renault's management had to hybridize them. In other words, the new methods became triggers, but they were activated, "pulled", by the company's management through hybridization.

This then opened way for the second phase: combination. The crisis from the mid1980s forced the company to engage in a strategic refocus on productivity gains. Once more, Renault's management took action and launched the Twingo Project and the QCD Operation. Moreover, the new Purchasing Director, Collin, combined the methods and qualifications identified by the organization in the previous phase, to develop one of the major elements of its supplier relation dynamic capability: the EAQF scheme. Here we see that the different elements of the dynamic capability were combined and activated so as to create an appropriation, with one central feature: it was inscribed in time.

The third and final phase of the process is the deployment of the dynamic capability within the organization. This phase was characterized by a form of saturation, during which, under the impulse of a new director, there was a double movement of acceleration and crystallization. It was no longer a matter of collecting and combining different inputs or factors, but rather of combining them firmly to be able to deploy them rapidly. That is why Renault turned towards lean manufacturing and a project-based organization, thereby finalizing the construction of its supplier relations dynamic capability.

The concepts of hybridization, combination and saturation therefore become a tool which comes to complete sequential approaches like that of Pablo et al. (2007) or Narayanan et al. (2009). But most importantly, they help us go beyond current explanations that identify generic hierarchical factors. Therefore, the construction of a dynamic capability depends not so much on the nature of independent elements that would be quasi-universal variables, but rather on a double process of crystallization of a variety of elements, triggered by managers. A historical approach therefore informs more on the eminently contextual nature of the construction of dynamic capabilities than on a general model that can be reproduced. 
Consequently, this empirical contribution presents normal limitations. The historical analysis of a unique case does not allow us to extend the conclusions to the theoretical and practical fields in general. It does, however, open new perspectives by introducing new concepts that help characterize with precision how a dynamic capability is built. The depth gained through this analysis and the emblematic character of the case within the automotive sector partly compensates its seemingly reduced scope. This is all the more relevant when we consider that as early as 1999, Renault entered an alliance with the Japanese manufacturer Nissan and thereby gained new horizons in terms of its supplier relations dynamic capability.

\section{References}

Adner, R. and Helfat, C. E. (2003), "Corporate effects and dynamic managerial capabilities" Strategic Management Journal, 24, 1011-1025.

Amit R., and Schoemaker P. J. H., (1993), "Strategic Assets and Organizational Rent", Strategic Management Journal, Vol. 14, 33-46.

Barney J. B., (1991), "Firm Resources and Sustained Competitive Advantage", Journal of Management, Vol. 17, 99-120.

Barney J. B., (1997), Gaining and Sustaining Competitive Advantage, Addison-Wesley Pub. Co, Mass.

Boyer R., Freyssenet M. (2002), The productive models. The conditions of profitability, Palgrave. Danneels, E. (2008), “Organizational antecedents of second-order competences", Strategic Management Journal, 29, 519-543.

Donada C., (1997), «Fournisseurs, déjouez les pièges des partenariats », Revue Française de gestion, Juin-Juillet, 94-105.

Eisenhardt, K.M. \& Martin, J.A. (2000), “Dynamic capabilities: What are they?",Strategic Management Journal,21(10-11), 1105-1121.

Fabre K., Nogatchewsky G., Pezet A. (2010), «Contribution à une histoire de l'externalisation. Le cas Renault (1945-1975) », Finance, Contrôle, Stratégie, 13/2, 145-188

Frank L. Douglas (2009), "Building Organizational and Scientific Platforms in the Pharmaceutical Industry: A Process Perspective on the Development of Dynamic Capabilities", British Journal of Management, Vol. 20, Issue s1, S25-S40.

Freyssenet M., "Renault: Globalization, But For What Purpose?", in Freyssenet M., Shimizu K., Volpato G. (eds), Globalization or Regionalization of European Car Industry?, PalgraveMacmillan, 2003, 103-131.

Helfat, C.E. \&Peteraf, M.A. (2003), "The dynamic resource-based view: Capability lifecycles" Strategic Management Journal,24(10), 997-1010. 
Helfat, C.E. \&Peteraf, M.A. (2009), "Understanding dynamic capabilities: Progress along a developmental path" Strategic Organization,7(1), 91-102.

Helfat, C.E., Finkelstein, S., Mitchell, W., Peteraf, M., Singh, H., Teece, D. \& Winter, S. (2007), Dynamic capabilities: Understanding strategic change in organizations, Blackwell.

Hochet, X., de Jaegere, A.B. (2010), Triggers. Transformer l'entreprise pour prendre un temps d'avance, Odile Jacob, Paris.

Lauer, S., (2005), Renault : Une révolution française, Éditions Jean-Claude Lattès.

Lippman S. A., et Rumelt R. P., (1982), "Uncertain Imitability : An Analysis of Interfirm

Differences in Efficiency under Competition”, Bell Journal of Economics, Vol. 23, 418-438.

McKelvie, A. and Davidsson, P. (2009), "From Resource Base to Dynamic Capabilities: an Investigation of New Firms", British Journal of Management, 20, S63-S80.

Midler, C., (1995), "Projectification" of the Firm, the Renault Case", Scandinavian Journal of Management, vol. 11, $\mathrm{n}^{\circ} 4,363-375$,

Monden, Y. (1983) Toyota Production System, Industrial Engineering and Management Press.

Narayanan, V.K., Colwell, K., Douglas, F.L. (2009), “Building organizational and scientific platforms in the pharmaceutical industry: A process perspective on the development of dynamic capabilities", British Journal of Management, 20, 25-40.

Nelson R. R., Winter S. G., (1982),An Evolutionary Theory of Economic Change, The Belnap Press of Harvard University Press.

Pablo, A.L., T. Reay, J.R. Dewald, A.L. Casebeer (2007), "Identifying, enabling and managing dynamic capabilities in the public sector", Journal of Management Studies, 44(5), 687-708.

Penrose E., (1959), The Theory of the Growth of the Firm, Oxford Basil Blackwell.

Post J. E., L. E Preston et S. Sachs (2002), "Managing the Extended Enterprise : the New Stakeholder View", California Management Review, vol. 45, n 1, fall, 6-28.

Post.J. E., L. E. Preston et S. Sachs (2002), Redefining the Corporation: Stakeholder Management and Organizational Wealth, Stanford University Press.

PrahaladC.K., Hamel G. (1990), « The core competence of the corporation », Harvard Business Review, 90, 3, 79-91.

Reeds R., De Filippi R.J. (1990), « Causal ambiguity, barriers to imitation and sustainable advantage », Academy of Management Review, 15, 88-102.

Rothaermel, F.T., Hess, A. (2007), "Building dynamic capabilities: Innovation driven by individual, firm, and network-level effects", Organization Science, 18 (6), 898-921.

Shingo, S. (1989), A Study of the Toyota Production System from an Industrial point of View, A. P. Productivity Press.

Teece D. J., Pisano G., etShuen A., (1997), "Dynamic Capabilities and Strategic Management", Strategic Management Journal, Vol. 18, 509-533.

Teece D. J., et Pisano G., (1994), “The Dynamic Capabilities of Firms : An Introduction”, Industrial and Corporate Change, Vol.3, 193-224. 
Wang, C.L., Ahmed, P.K. (2007), "Dynamic capabilities: A review and research agenda", The International Journal of Management Reviews, 9(1), 31-51.

Wernerfelt, B., (1984), “A Resource Based View of the Firm”, Strategic Management Journal, Vol. 5, 171-180.

Zahra, S.A., Sapienza, H.J. \&Davidsson, P. (2006), "Entrepreneurship and dynamic capabilities: A review, model and research agenda", Journal of Management Studies, 43(3), 917-955.

Zald, M. N. (1991), "Sociology as a discipline: Quasi-science and quasi-humanities", American Sociologist, 22, 165-187.

Zald, M. N. (1993), "Organization studies as a scientific and humanistic enterprise-Toward a reconceptualization of the foundations of the field", Organization Science, 4, 513-528.

Zald, M. N. (1996), "More fragmentation? Unfinished business in linking the social sciences and the humanities", Administrative Science Quarterly, 41, 251-261.

Zollo, M., Winter, S.G. (2002), "Deliberate learning and the evolution of dynamic capabilities", Organization Science, 13(3), 339-351. 
Figure 1

1975

Macro-economic context

Demand > Offer

Inflation

Sectorial context

IT development

Renault 's context

Meet demand

internationalization

American Motors

1985

1995

Slowdown

Growth

Globalization

Toyotism model for QCD

Project management model

Alliance

with

Nissan

Privatization

Massive externalization

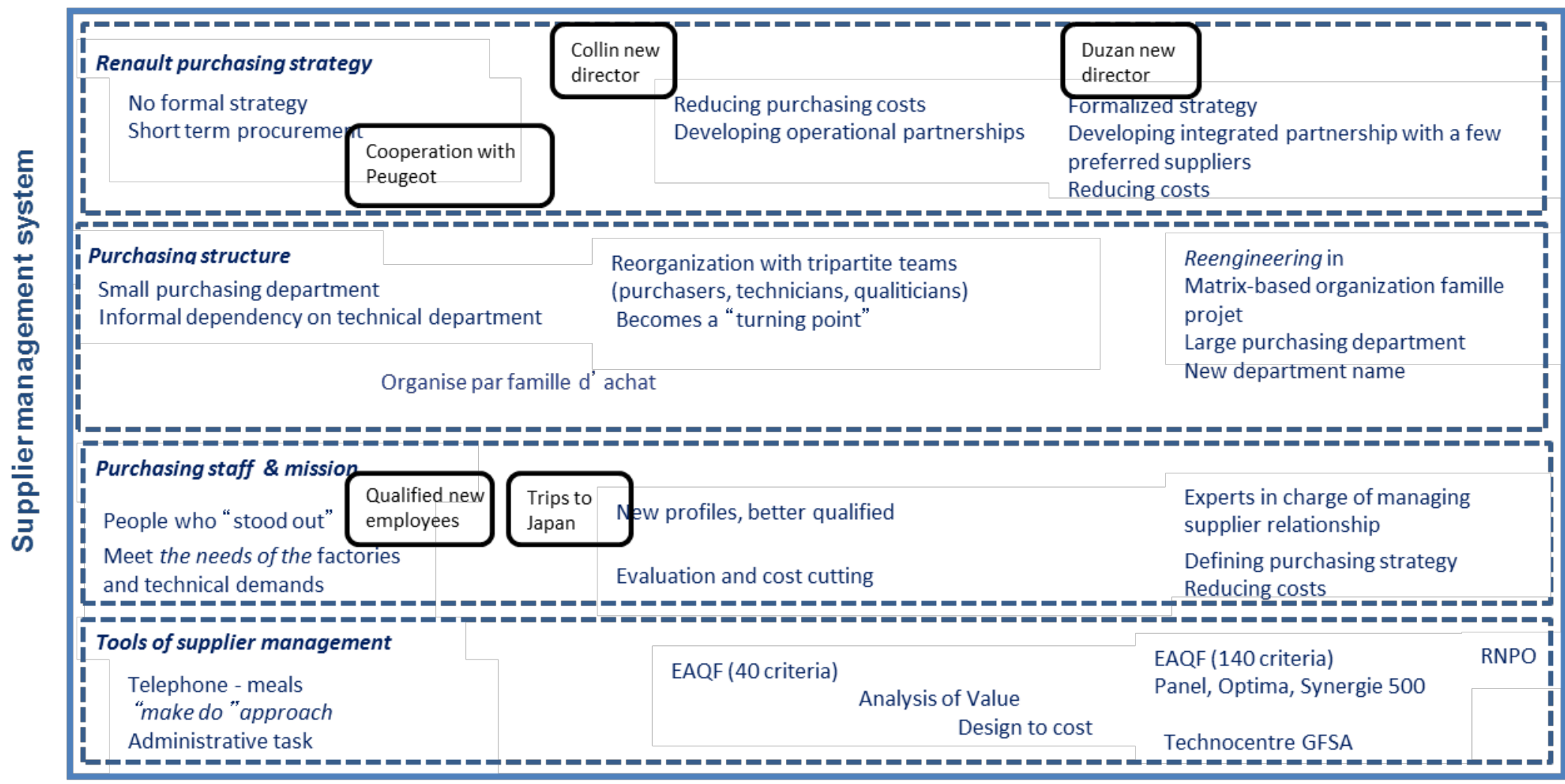

\section{Supplier relationship}

Arms length with heterogeneous

SMES

Subcontracting

\section{Operational cooperations}

First partnerships

$\mathrm{Nbr}$ of suppliers divided by 100
Partnerships with large OEM and systemiers 
Figure 1

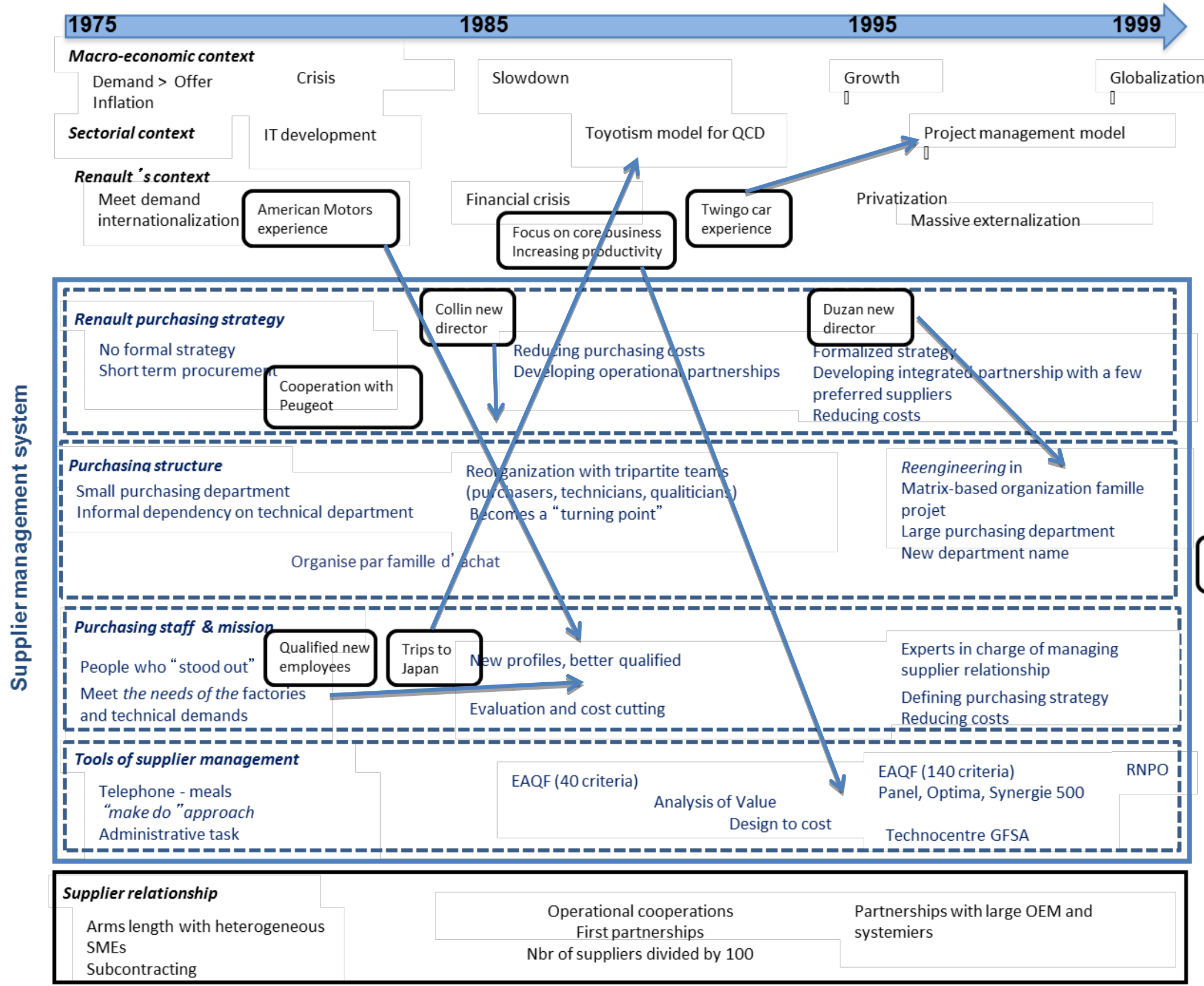

Alliance

with

Nissan 
ESSEC Business School Avenue Bernard Hirsch BP 50105

95021 Cergy-Pontoise Cedex France

Tél. +33(0)134433000

$\mathrm{Fax}+33(0) 134433001$

www.essec fr

\section{ESSEC Executive Education}

CNIT BP 230

92053 Paris-La Défense France

Têl. + $33(0) 146924900$

Fax +33 (0)1 46924990

http://formation.essec.fi

ESSEC Business School

Singapore Campus

100 Victoria Street

National Library Building \# 13-02

Singapore 188064

essecasia@essec.fr

Tél. +6568849780

Fax +6568849781

www.essec.edu

Informations

+33 (0)134433358

www.essec.fr

research.center@essec.fr

ISSN 1291-9616 